\title{
Dare the School Build a New Social Order?
}

\author{
Tony Robinson \\ University of Colorado - Denver
}

\begin{abstract}
Service-learning proponents are divided over direct charity versus justice-advocacy models, with many claiming a need for justice-advocates to moderate their service-learning philosophy in order to secure long-term institutional support. Historical examples of the Settlement House and Students for a Democratic Society teach that justice-advocacy service-learning has a long tradition but finds trouble in institutionalizing itself. Nevertheless, justice-advocacy service-learning should be pursued vigorously, for in it the university realizes higher goals of catalyzing social progress while simultaneously providing fundamental citizenship-education to students. A current justice-advocacy service-learning program at UC-Denver provides a case study.
\end{abstract}

"Dare the school build a new social order?," George Counts (1932) once asked in the title of his call to educational justice-advocacy. "Yes," Benjamin Barber (1999) once responded to a similar question at a service-learning conference, "but not so bluntly." Barber agreed that the service-learning movement, to achieve its oft-stated goals of social improvement, needed to have something of an activist or advocacy edge, but he argued that such a stance could not be pursued too openly nor aggressively, for fear of losing service-learning's institutional support and academic integrity. Edward Zlotkowski (1996) expresses a similar fear that excessive attention to the ideological aims of justiceadvocacy and inculcating moral and civic values in youth will harm the ability to institutionalize service-learning among a broad range of faculty, many of whom look to service-learning as a tool to enhancing classroom learning, pure and simple, without associated concerns for "justice-advocacy" or "inculcating civic morality" (especially those in the less political disciplines, such as biology or engineering).

Zlotkowski (1996) argues that service-learning advocates spend excessive energy debating whether service-learning should follow a "charity" model, a "citizenship" model, or even a "justice-advocacy" model, and too little energy on how to make servicelearning applicable to a wider range of disciplines. "Unless service-learning advocates become far more comfortable seeing 'enhanced learning' as the horse pulling the cart of 'moral and civic values,' and not vice versa," he fears, "service-learning will continue to remain less visible - and less important - to the higher education community than is good for its own survival" (p. 4).

Zlotkowski (1996) further posits that servicelearning advocates face some fundamental choices:
Do they represent a movement of socially and morally concerned activists operating from an academic base or a movement of socially, morally, and pedagogically concerned academicians?

What ultimately takes priority in their discussions and writings: the suitability of moral and civic concepts such as 'charity,' 'citizenship,' and 'justice,' or the pedagogical rationales that allow engineers and dancers as well as sociologists and political scientists to see service-learning as directly relevant to their work? (p. 7)

I share Zlotkowski's conclusion that a politicallycharged service-learning movement is unlikely to attract the support of a wide range of faculty or to find enduring institutional support. However, considering the depth of the social and political challenge that confronts us, the high purpose of the university to set forth a vision of human improvement, and the educative benefits that will result, it is still vital to push for an activist-oriented, service-learning movement. We must push as hard as possible, while it is possible, for we indeed may expect just what Zlotkowski predicts: an ultimate repeating of the "periodic mortality" that has ended similar social change movements of the past (e.g., the 1900's, the 1930s, the 1960s). The dominant academic culture simply will not adopt the "social activist" bent of much of the service-learning movement, Zlotkowski correctly notes. "I know my faculty colleagues well enough to assert that marching across campus beating even a big drum will not induce most of them to drop what they're doing to join a parade" (1996, p. 26). This is all too true; as before, this kind of reform movement will surely pass. But the most must be made of it while it lasts.

A vital task is to push the extant service-learning movement into ever more activist political engage- 
ment and courageous social stands. The question should be how to build on the service-learning movement to catalyze a broad educational and social reform movement, how to reassert the role of the university as a source of social critique and progress, and how to educate citizen-students who are able and willing to critically engage a society deeply in need of reform. In this regard, the lesson of Piven and Cloward in their classic work, Poor People's Movements (1977), should not be forgotten: true transformation and serious progress on issues of social equity happens during times of unrest and turbulence, when institutions (including universities) are pushed by all manner of unsustainable movements and radical innovations. Similarly, Counts (1932) argues that the heart of a socially responsive education movement must be the revolutionary commitment to challenge the powerful and ruling classes and to "manifest a tender regard for the weak and unfortunate," while placing "the heavier and more onerous social burdens on the backs of the strong" (p. 41).

The fact that other groups refuse to deal boldly and realistically with the present situation does not justify the teachers of the country in their customary policy of hesitation and equivocation. The times are literally crying for a new vision of American destiny. The teaching profession, or at least its progressive elements, should eagerly grasp the opportunity which the fates have placed in their hands. (p. 53)

Full advantage must be taken of such moments, for once accommodation to broader powers (e.g., the wider university community) begins to set in, serious social progress will stall. In other words, and in the tradition of George Counts, carpe diem.

Undeniably, Zlotkowski is right: a primary goal of universities is the education of students, pure and simple. But the service-learning movement is rightly committed to standing for something more than what Finn and Vanourek (1995) suggest as the "core mission" of the university: "transmitting basic skills and essential knowledge" (p. 7). Service-learning proponents look beyond the education of individual students to broader goals, summarized by Plato's vision of the educated intellectual-bringing the liberating light to an oppressed society. In less dramatic prose, this kind of goal underlies much of the language of service-learning practitioners. "As the custodians of knowledge won at social expense, we have the solemn duty to make that knowledge useful to society," Commoner (1968, p. 25) argues. "How can public education help prepare our youth to sustain a just and humane democracy," ask Schaps and Lewis (1998, p. 1). Barber and Battistoni (1993) call for what they term a "pedagogy of freedom," "...an indispensable prerequisite of citizenship and thus a condition for democracy's survival" (p. 10). Such arguments are prevalent among service-learning proponents, who commonly look beyond the potential of service-learning to enhance the education of students, per se, and argue that service-learning programs can: "heal a divided society" (Barber, 1999), "cure the pathologies of society" (Gorham, 1992, p. 8), equalize life-opportunities (HUD, 1999), and restore a sense of civic connection and responsibility (Bass, 1997). Some scholars go so far as to conclude that service-learning is "crucial to the survival of American society" (Kraft, 1999, p. 8).

However, the service-learning movement is far too popular with corporate and governmental funders, and far too civil in practice, to be doing its job well in these regards. Healing social divisions, curing pathologies, rebuilding civic connections, and saving a society takes the mobilization of a tremendous social and political movement for change. It will entail social and political conflict, especially with the current holders of privilege and power. It will involve people in political advocacy. If we are serious about achieving the healthy kind of democracy about which so many in the service-learning movement write, then it should be very clear that:

\begin{abstract}
Powerful classes must be persuaded to surrender their privileges...And according to the historical record, this process has commonly been attended with bitter struggle... There is little evidence from the pages of American history to support us in the hope that we may adjust our difficulties through the method of sweetness and light. (Counts, 1932, p. 51)
\end{abstract}

Achieving the broad social goals advocated by many service-learning practitioners will require those in the academy not to deny the goals of student education or professional research, but to unite those goals with an equal calling-acting as the spark and engine of social progress, speaking truth to power, and channeling knowledge, resources, and political power to those who need it most. Such a stance can be expected to generate conflict with, and even hostility from, the wider society.

\section{Service-Learning Citizenship: Charitable Volunteerism or Political Advocacy?}

Underneath widespread agreement that servicelearning can address social problems, develop moral virtue, and build strong citizens (Barber, 1998; Barber \& Battistoni, 1993; Bass, 1997; Carr, 1991; Chickering, 1998; Etzioni, 1983; Gorham, 1992; Nyden, Figert, Shipley \& Burrows, 1997; Pickeral, 1996; Rhoads, 1997; Rimmerman, 1997; Stringer, 
1997), there is a division of thought concerning the proper model of service-learning. The division emerges between that kind of service-learning that is the provisioning of direct, charitable services to communities in need (food drives, painting houses, street cleanups, counseling), and that kind of service-learning that engages students in political organizing and advocacy for social change. More service-learning nationwide is of the first sort than the second; in fact, social-advocacy service-learning (the "justice-advocacy model") is widely discredited across the academy.

Almost all service-learning practitioners argue that service-learning has the capacity to rebuild civic society, and even to communicate "the goal of social justice" (Rocha, 2000, p. 53), but few of them espouse the kind of system-challenging servicelearning that would be necessary to achieve such goals. Practitioners are exceedingly nervous about service-learning curriculums that entail political challenge to the established order, or involve students in taking political sides and creating transformational movement. Gorham (1992) argues that the unfortunate truth is that many service-learning programs operate by the "charity model," as opposed to promoting social transformation. Such service programs, which focus on linking individual students to charitable service-projects (e.g., letter-writing to homebound elders, house-painting, serving food in a soup kitchen), are driven by a language of victimtherapy and "helping," rather than by a language of political resistance, conflict and social transformation.

These modern service-learning programs are filled with students committed to individual acts of charity, but who are deeply cynical regarding political action as a solution to social problems (Carpini \& Keeter, 2000) - a far cry from the committed social activists of the 1890s, 1930s or 1960s. Ours is a rather sedate, even conservative, political era, and is hardly a time of political turbulence and incipient social transformation. Few service-learning academicians, political leaders, or even students are calling for a politicized justice-advocacy social movement, which is exactly Zlotkowski's point and his reason for suggesting enhanced attention to the pedagogical benefits of service-learning, rather than its social agenda and progressive political effects.

In such an era, what is the basis for calling for such a risky, and possibly unpopular, politicized service-learning movement? One response to this dilemma is for justice-advocacy service-learning proponents to focus more clearly on the pedagogical rationale for their programs and less on the ideological goal of social transformation. The university has always had two core missions. One is the production of knowledge and education of students, pure and simple and in politically neutral fashion. The other is to act as a kind of social conscience and spark of progress, and to advance the power of reason, tolerance, and justice in the world, especially when these principles are opposed by military might or sheer economic power. James Carr (1999) cites Harkavy, who agues that the university is "an institution whose mission is the general mission of society improvement and democratic improvement" (p. 8). Since this mission tends to involve contentious activity and faces frequent challenges from those defending the "neutral" university as a site of nonpoliticized student learning, it behooves those oriented toward politicized service-learning to uphold the fundamental pedagogical benefits of such programs. If educators can more clearly make the case for the pedagogical benefits of political, socially critical, and justice-advocacy forms of service-learning, then they can expect that the transformational social/political/economic aims of their servicelearning programs will be more easily realized as the programs are more easily sustained. Educators must emphasize that the lessons taught and the life-habits learned through critical social engagement and antiestablishment justice-advocacy are vitally important and cannot be as effectively learned from either "book-research" or from common models of charitable, direct-service service-learning, such as tutoring, ESL instruction, or food drives. Some service-learning proponents are doing exactly this. In addition to a wide range of scholars noting the educative benefits of service-learning in general (whether of the dominant direct-service, charitable type or of the more rare political version), some scholars are specfically examining how politicized brands of service-learning teach important values (engagement, creativity, the strategy and necessity of collective action) that less politicized brands cannot (e.g., Boyte \& Farr, 1997; Walker 2000).

\section{Dominant Service-Learning Models}

The fact remains, however, that academic treatments of the educative benefits of politicized service-learning are rare, as compared with the myriad examinations of more charitable, direct-service programs. Scholars continue to promote dominant strains of service-learning that adhere to the philosophy expressed by the general counsel for the Corporation for National Service: "National service has to be nonpartisan. What's more, it should be about bringing communities together by getting things done. Strikes, demonstrations and political activities can have the opposite effect. They polarize and divide" (quoted in Walker, 2000, p. 647).

In accordance with this view, most service-learn- 
ing programs have two characteristics. First, the programs place students with established, professional, and mainstream organizations and agencies. These agencies range from government offices to homeless shelters, local schools, computer training centers, foundation offices, housing authorities and welfare administration agencies. Second, students are generally placed in non-politicized roles, offering technical assistance and direct services to communities and individuals, ranging from professional planning research to computer training, tutoring, client counseling, housing rehabilitation, and park construction. Though service-learning programs are often situated in communities that have been devastated by the extant political-economy, and though such communities are often filled with both inchoate and organized expressions of rage and discontent with this system, students are rarely encouraged to find service-learning experiences that would involve them in organizing and harnessing this rage, in generating a power-seeking advocacy politics in the community, or in fostering political defiance against the established order.

In the National Library of Education's 1998 compilation of service-learning experiences, some common programs mentioned were AmeriCorps, Learn and Service America, Habitat for Humanity, Big Brothers and Sisters and soup-kitchens. Even in the 1997 American Association of Higher Education (AAHE) volume on service-learning within political science, common service-learning placements were with homeless shelters (serving food and providing counseling), tutoring, working at women's crisis centers, after-school programs, and interviewing welfare clients. In HUD's ambitious attempt to catalogue 599 college service-learning programs, the results were as follows: $50 \%$ of all programs were direct-service programs (tutoring, serving food, clothes collections, blood drives), $42 \%$ provided technical assistance (leadership classes, computer training, planning studios, grant-writing assistance), $7 \%$ were mostly involved in physical revitalization (business incubation, tree planting, housing renovation), and only $1 \%$ were political advocacy programs (building tenant councils, drafting legislation, challenging officials with organized groups of residents) (see also Hepburn, Niemi, \& Champman, 2000; Kraft, 1998).

We are neglecting activities that address the structural roots of problems, that work to unite citizens in action for change - organizing tenants, union members, homeless people, and welfare recipients. Such political organizing, entailing an action-oriented critique of society, is anathema to today's servicelearning proponents. Painting the decaying homes of low-income renters with student labor brings cele- bration, but working with renters to build a tenants' union or mobilize a rent strike to address systematic exploitation by slumlords is widely avoided.

\section{The Pedagogy of Charity}

The dominant model of charitable service-learning has powerful implications for the type of citizenship and political action that is appropriate for our society. This is the kind of service-learning advocated by both Presidents Bush ("a thousand points of light") and Clinton (Americorps), a kind of service-learning that can find bipartisan support because it merges concepts of citizenship with notions of apolitical volunteerism and charity (Kahne \& Westheimer, 1996). Without focusing on structural injustices and the necessity to mobilize force to change them, such a peaceful and polite model of service-learning attracts even a conservative like George Bush, who denies the role of government in solving problems that can be best addressed "by a vast galaxy of people working voluntarily in their own backyards" (quoted in Kahne \& Westheimer, 1996, p. 594). Such an "apolitical ideology of service disables the civic," Gorham argues (1992, p. 118). Service-learning curriculums focusing mainly on bricks and mortar projects, on working as a hospital aide, on assisting at a homeless shelter or soup kitchen, though they deliver many benefits to individuals in need, silence the citizen and constitute more of a glorified welfare system than a socially transformational movement.

The pedagogical problem with these statistics is that if service-learning merely inputs students into service-jobs that deal with the fallout of the system, then it is poor training for critical citizenship, political reasoning, or social transformation (Gorham, 1992; Walker, 2000). A service-learning language of individualistic therapy and "helping," rather than a language of political resistance, conflict and social transformation, silences students as agents of political and social change as they are plugged into "existing social service and governmental agencies who are setting the agenda" (Lisman, 1997, p. 82). Reflecting on her experience with Americorps, Claudia Horwitz concludes that:

National service is sapping the energy of many of our nation's most powerful young leaders...[perpetuating] the myth that community service is enough to address serious social problems...Bold claims are being made that are actually doing a disservice to the young people who have much more potential to do social change organizing...We cannot expect serious social change without a critical analysis of our political, economic, and social systems--an analysis that national service will not 
allow. (1993, pp. 1, 6)

Defining one's service to society in this way actually carries the possibility of normalizing and domesticating the commitment to social justice and community transformation that drove many to service-learning in the first place. If the path we and our students follow in responding to our "hunger for justice" (James-Deramo, 1999) is to work in complicity with large and professional non-profits and the agencies of the state, then we are not only normalizing and civilizing our own radical sentiments, but we may also be acting to normalize and civilize the radical tendencies to defiance and unrest that exist within the communities we serve. When service-learning programs plug students into the dominant case-management, individual counseling, client supervising, and professional agencies of the state and into the "shadow state" nonprofit world (Wolch, 1990), and when they turn students away from grass-roots mobilization, street protests, and insurgent defiance politics, then they function to domesticate both service-learning and latent student passion by turning potential activists, social workers and public servants away from the forces of social transformation and toward the forces of stability, normality, and preservation of privilege.

This is a harsh criticism, and it deserves a bit more elaboration. Regarding the dilemmas of servicelearning work with established and generally professional nonprofits, there are three concerns. First, these non-profits tend to displace clients' needs with attention to their own organizational survival needs-needs that are commonly met through client acquiescence, organizational stability, and the nurturing of good will with powerful political and business leaders. Second, non-profits today tend to offer very little in terms of organizing a political challenge to the existing social structure that creates the profound human problems that they deal with daily. Rather, non-profits have generally substituted individual case management and treatment of individual pathologies for broad political organizing and challenges to the existing social structure. Third, established non-profits over time tend to become skeptical of the abilities and insight of their "dysfunctional" clients, advancing the expert's claim that the case-manager knows best what is needed for the individual and for the community. (For scholarly attention to all these claims, see Arnove, 1980; Clotfelter, 1992; Cloward \& Piven 1975; Katz, 1996; Mead, 1997; Piven \& Cloward, 1993; Salamon, 1992). Basing the vast majority of our service-learning experiences in these environments will tend to produce similar tendencies in our studentsthus effectively domesticating whatever "wild" impulses to social transformation might have drawn them to social work and public service in the first place.

These developments emerge in a surrounding political environment that denigrates poverty advocacy, overlooks systemic problems in favor of an individualistic analysis of poverty, and generally absolves wider society of responsibility for addressing the problems. To survive and find social support in this environment, non-profits have been forced to devalue and diminish their political advocacy and social criticism work so prevalent in the 1960s in favor of case-managing the poor and even extracting penalties of intimidation, insult and degradation from the clients passing through their programs (Bailey \& Brake, 1975; Katz, 1996; Piven \& Cloward, 1993). Increasingly, nonprofits working with degraded populations (the poor, the unemployed, the disabled) have adopted what Biddle and Biddle once called a "consensus-cooperation" approach. The social worker "should NOT be or should never become a destroyer of the social order," they have argued. "By using or endorsing the idea of revolution, he can find himself disqualified to act as a mediator between factions in controversy" (quoted in Mayo, 1975, p. 137).

These kinds of social workers play a powerful role in de-politicizing potential unrest in their communities by neglecting political mobilization and by developing an individualized case-management approach to poverty that minimizes attention to broader social oppressions and emphasizes the individual's role in creating and rectifying their own troubled situation. Together with case-workers, our service-learning students are pushed to discourage obstreperous and defiant clients, to avoid involving themselves or their "clients" in insurgent street politics, and to pathologize, not politicize, their work with impoverished "clients."

Such supervisory approaches to poverty often create tension between impoverished citizens and their service-providers who design all manner of imposing rules and systems of control to manage, supervise, and evaluate them (e.g., homeless shelters, public housing agencies, Temporary Assistance for Needy Families administration agencies, job counseling centers). Because the vast majority of our service-learning programs place students with a nonprofit or state agency itself, students experience this dilemma from the perspective of the agency, not from the perspective of the clients, who are often filled with discontent at the agency itself and at the wider socio-political environment that spawned the problems with which they must deal. The number of students placed with homeless shelters and case management programs dwarfs the numbers of stu- 
dents placed with politicized advocacy groups dominated by the homeless themselves; students are placed with welfare administration offices and nonprofits working to implement welfare reform, and rarely are they placed with coalitions of welfare families who are organizing to challenge and overturn these offices. These facts should concern anyone interested in the educational and developmental consequences of service-learning on students.

Piven and Cloward (1993) and Michael Katz (1996) have documented the historic process by which new social workers (such as our servicelearning students) have been led to adopt professional attitudes of neutrality and the "case-management" approach, which functions to "paralyze reform" and "reinforce the status quo."

\begin{abstract}
The reformers' path to professionalism tied the management of social change to the development of their own careers. Along with university-based social scientists, who had faced similar career problems a few decades earlier, they made the trip from "advocacy to objectivity" by resting the case for their authority and importance on the capacity of neutral experts to find technical solutions to complex problems. Somehow, those neutral technical solutions usually supported whomever it was that paid the bill. (Katz, 1996, p. 176)
\end{abstract}

Developmentally, these patterns of service-learning moderation function to normalize and domesticate the potentially radical sentiments of students and faculty drawn to public service, while helping ensure students a place in the non-profit and public administration bureaucracies. Although recruits to these fields are often drawn by an ideology of social progress and even by a fundamentally radical critique of society (Pearson, 1975), learning a place in established bureaucracies requires that students forgo radical critiques and disruptive politics in exchange for a personal job and the ability to help individual clients, usually through case management. In the words of Mendel-Reyes, service-learning placements as counselors, tutors, or grant-writers often prepare students for these realities. Servicelearning students are prepared not for a life as the socially disruptive intellectual, but for "what Plato might have called philosopher middle-managers" (Mendel-Ryes, 1997, p. 20).

Service-learning advocates should show a greater awareness of this dynamic and a greater willingness to second-guess the universally celebrated benefits of channeling students into soup kitchens, homeless shelters, planning agencies, and family counseling programs. Such experiences are valuable and socially productive, when judged on their own merits, but when seen in the broader context of a service-learn- ing movement that is generally absent of more politicized opportunities to engage in radical protest politics or in organizing defiant movements of tenants or the homeless (for example), then these nonpoliticized service-learning programs must be more carefully critiqued. Such programs serve a conservative political and educational function, channeling student energy into the professionalized, therapeutic, direct-service work of established agencies, instead of linking a student's subjective desire for social engagement to creative, challenging, and even radical forms of social action.

There are more politicized models of servicelearning, of course, ranging from one proposed by California's Center for Civic Education (which seeks to build students' competence to monitor and influence public policy) to Ralph Nader's "Civics for Democracy" model that urges consumer advocacy and pressure tactics on problem businesses and nonresponsive politicians (Finn \& Vanourek, 1995). Boyte and Farr (1997) also are critical of a directservice form of charitable, non-political servicelearning, and they propose a "citizenship education" model that engages students in deliberating and working together to solve public problems. Boyte and Farr argue that involving students in this kind of creative citizenship serves the educative purpose of "liberating" students from typical, mainstream "professional practices and identities" (p. 6) by providing students with "the transformational experience of their lives" (p. 1).

Elaborating the kind of pedagogical benefits from politicized service-learning programs might help to popularize and institutionalize this model of servicelearning, even among the more skeptical and moderate wings of the academic community. But this result is unlikely. A more likely result will be only marginal acceptance of politicized service-learning. It is only in rare moments of broad social transformation that such politicized university programs can be expected to enjoy wide support. (e.g., the 1960s). Service-learning practitioners cannot create, nor predict, such bursts of social reform and serious political engagement, but they do help to prepare the way and to catalyze that burst through their enduring faith in engaging students in productive political action and social work. By serving as a social catalyst, the university confronts established powers with ideals of justice, tolerance and equity, serving as a kind of social conscience and acting as the spark of social change.

This role of the university has strong historic precedent, with the turn-of-the-century and the 1960s providing perhaps the most dramatic examples of what the university has been and of what it can become. During the height of these reform eras, 
notable educational theorists did not shy from justice-advocacy. Rather, they rose to the occasion, unabashedly committed their intellectual and moral energies to social progress in the face of serious political resistance, and advanced a theory of the "relevant" university-one that stood up to and spoke truth to power. The great advances made during those eras (e.g., child labor laws, inclusive democratic processes, consumer protections, free speech rights, civil rights, and ending the war in Vietnam) were the result of an advocacy-oriented "service-learning" movement unafraid to make political stands and to take the reins of power wherever possible. It is to these historical moments and this theory of university activism that I now turn.

\section{Jane Addams and the Settlement House}

Harkavy and Benson (1997) have detailed the foundational role played by turn of the century educational and social reforms that converged to "put into practice a theory of instrumental intelligence that has served as the philosophical basis of academic service-learning" (p. 5). Several great universities like Columbia, Johns Hopkins, Pennsylvania, and Chicago all began their climb to prominence by directly engaging their urban communities and "by working to improve the quality of life in American cities experiencing the traumatic effects of industrialization, immigration, and large-scale urbanization" (p. 5). This engagement included such explicitly political work as advocating against WWI, promoting fair labor laws, and playing a leading role in urban political reform movements.

One of the most noted of the university-linked "service-learning" practitioners was Jane Addams, a well-educated woman of affluence, who in the 1889 turned her despair at the horrid slums of America into action for change by opening the doors of Hull House in the midst of Chicago's Southside slums. Hull-House marked the beginning of America's "Settlement House" movement, and, in a larger sense, marked the beginning of formal social work in America. It also directly influenced the emergence of the Chicago School of Sociology (Commager, 1960).

In the heart of the degraded Chicago slums, at the very core of the meatpacking slum district, Jane Addams opened Hull-House: "a clearinghouse for every kind of social service, an experimental laboratory in social reform...she made it a school of citizenship and a university of social service" (1910, p. xii). Addams welcomed both the poor and the educated to the various service-activities of Hull-House: food giveaways, English instruction, medical care, schooling, arts and culture celebrations, drug, alcohol and mental counseling. Hull House also became a center of political agitation, pushing new labor laws, establishing juvenile courts, gaining new schools and paved roads for the neighborhood, securing better enforcement of housing and sanitation laws, pushing for woman's suffrage, politicizing immigrants, and resisting World War One.

Hull House brought the university-educated into productive relationship with the uneducated and impoverished residents of Chicago's slums. For Addams, this ability of the Settlement House to fulfill the moral needs of the young, affluent and educated, and to educate them concerning their own society, was as important a reason for Hull House as was the need to ameliorate horrific social conditions. A soaring vision of "high purpose," "persistently haunts the young," Addams believed (1910, pp. 38, 58). And yet the youth of her age were well aware of how easy it was to "abandon" these ideals, and to become content "with a shadowy intellectual or aesthetic reflection" of the world instead of really acting on these ideals by fighting for the oppressed "in a really living world" (p. 58). Young people of her time were "seeking an outlet for that sentiment of universal brotherhood...These young people accomplish little toward the solution of this social problem...They feel a fatal want of harmony between their theory and their lives, a lack of coordination between thought and action" (p. 91).

Addams laid part of the blame on the universities. Abstract book study, divorced from engagement with social issues, cultivated high intellectual ideals but also deadened the automatic response to human suffering that youth tended to feel upon entering higher education. Although "the desire for action, the wish to right wrong and alleviate suffering haunts [the young] daily," and although universities often inspired young people with an idealistic commitment to addressing social problems, young people were provided with few avenues to express these desires while in school.

As a response, the Settlement House provided avenues of direct social action to the educated and idealistic. Tutoring, muckraking journalism, and legal advocacy were some of the roles university partners played at Hull House. Addams did not steer Hull House and its friends away from political engagement and justice advocacy. Indeed, she lived amid the great "echo of the Russian Revolution," as she called it, and she believed such a revolution could only be avoided in America if the educated committed themselves to working politically to solve social problems, to altering the existing structures of power, to constructing a social democracy at home. Correspondingly, the Settlement House brought its university collaborators into serious social, political, and economic reform movements 
dedicated to aligning the industrial system with a more humane set of ethical demands, to politicize the impoverished, and to legal reforms (minimum wage laws, child labor laws, union protection acts) to alleviate poverty.

Deploying university resources for explicitly political social reform proved extraordinarily fruitful. "It was no accident," Commager (1960) argued, "that the new University of Chicago, which was founded just a few years after Hull House, came to be the center of sociological study in America, and that so many of its professors were intimately associated with Hull House" (p. ix). Though Hull Houseinfluenced sociology soon developed into a dispassionate social science, dominated by the scholarship of academic distance and scientific objectivity, many early academicians associated with Hull House were committed to a scholarship of action and reform. The era of reformist activism, both politically and educationally, ultimately came to an end around the time of WWI, but the great gains that we now attribute to the Progressive era had already been won-through the hard work of political activism, both in the streets and on the campus.

\section{SDS and the Engaged Campus}

The Settlement House philosophy of the politically engaged campus was to powerfully re-emerge in the 1960s. The general philosophy of the student movements of the 1960s is well expressed in the 1962 Port Huron Statement. Emerging from a conference of students who were dismayed at the political lethargy of the day and at the lack of courageous effort in addressing America's problems of poverty, race, alienation, and militarism, The Port Huron Statement detected a listless ennui among youth of the era: "We are people of this generation, bred in at least modest comfort, housed now in universities, looking uncomfortably to the world we inherit" (quoted in Miller, 1987, p. 329).

For these youth, few avenues were provided to act on their ideals. "We ourselves are imbued with urgency, yet the message of our society is that there is no viable alternative to the present...For most Americans, all crusades are suspect, threatening. The fact that each individual sees apathy in his fellows perpetuates the common reluctance to organize for change" (Miller, p. 330). But the students of Port Huron, did not accept this state of affairs. Tom Hayden, the document's author, argued that "I don't think there's anything more satisfying politically than to be young in spirit, and to believe the world is yours to change. And there's nothing better than to set a living example, if you can, by associating yourself with the victims of social injustice" (Miller, p. 325).
As with Addams, the Port Huron students, and many of the educational theorists of the day, openly committed the university to justice-advocacy. The goals of the students were to address, in a real way, the myriad social, economic and political problems detailed in the Port Huron Statement, to become "the spark and engine of change" (quoted in Miller, 1987, p. 331), and to produce a more democratic social, economic and political system. One of the means to this end was to engage people, especially the idealistic young, in participatory political action and social service, in order to confront the general atrophy of political and social engagement that had led to a collective American malaise, an "emptiness of life" (Miller, p. 330), and to a general "withdrawal from public life" (Miller, p. 335).

The authors of the Port Huron Statement looked to the educated youth of the universities to challenge this state of affairs. But they went beyond the volunteeristic, charity model suggested by Clinton's Americorps and Bush's "Thousand Points of Light." Rather, they explicitly sought to build political power, to practice participatory democracy, and to politically influence the direction of their nation. Marches, sit-ins, alternative political parties, rent strikes, civil rights activism, welfare rights organizing, and burning draft cards represented the dominant themes of student activism more than did paint-a-thons, blood drives, and neighborhood cleanups. Some of the more vocal advocates of an engaged pedagogy, such as Michael Harrington (1968), realized the political dangers that such an activist stance entailed for the university, but were willing to take the risks. The students of Port Huron agreed. "From where else can power and vision be summoned?" the students asked. "We believe that the universities are an overlooked seat of influence." It is from the universities that students hoped to "build a base for their assault upon the loci of power" (Miller, 1987, p. 374).

In specific terms, the kinds of university-community collaboratives sought by the Students for a Democratic Society (SDS) became such projects as the Economic Research Action Projects (applied research and political organizing in low-income communities), civil rights organizing, collaborating with the various projects of the War on Poverty, The Mule Train march on Washington, renters and welfare rights organizing, and the struggle to organize farm workers. While the 1960s proponents of engaged pedagogy shared the goal of modern service-learning proponents to get students beyond the sterile confines of university classrooms and into the streets, they pushed the scholarship of action much further than we do today-committing the university to fundamental social transformation (Mendel- 
Reyes, 1995).

The examples of Hull House and SDS are not only important in their own right, but also for what they teach about the surprises of history. There are few signs of 60 s style unrest and reformation today, but neither were there many such signs back then, before the reform movements emerged. When Addams began her lonely Hull House experiment, Chicago's slums were unrelieved blocks of brutality, the University of Chicago did not exist, and educated students were more apt to spend time on grand tours of Europe than in service-work in the slums. In the late 1950's, similarly, no one could have predicted what was to come. Leading scholars of "American consensus" such as Seymour M. Lipset and Daniel Bell were busy writing about "the end of ideology" and of how America had solved all fundamental problems, leaving progressive intellectuals with little to do but look overseas for useful activity. And yet, in both cases, lonely experiments in socially engaged "service-learning" rapidly catalyzed national reform movements (together with many other factors), politicized an era of new student leaders, and changed the history of the country. Could conditions today predict a similar occurrence? Then, as now, calls for educational "relevance" were sweeping the field. Then, as now, a sustained period of economic growth and prosperity had put America awash in money, but had left millions in deep poverty as the gap between the classes grew and basic problems like housing and health care were exacerbated for the poor. Then, Todd Gitlin (1987) detected the same "mainstream moral panic" (p. 146) — bred from isolation and a lack of civic engagement-that Robert Putnam (1995) detects today as Americans increasingly "bowl alone."

We have important lessons to take from the past. Remembering the role played by the politicized university in achieving social progress is critical to helping today's service-learning movement achieve its oft-stated goal of "reclaiming democracy." To achieve that goal, it will serve us well to remember the bold vision shown by those such as Jane Addams and SDS. "Our ability to act politically, to begin something new, depends on knowing where we have come from and where we are," Mendel-Reyes (1995, p. 26) notes. In her review of the political movements of the 1960s, Mendel-Reyes shows how deeply participatory and democratic that era was, a model that we tend to forget while designing service-learning programs around individualistic direct-service work as opposed to participatory political action. "Instead of drawing inspiration and valuable lessons...from the country's most recent experience of participation on a large scale, we have nearly forgotten that ordinary people took democra- tic action to bring about more democracy, and could do so again" (Mendel-Ryes, p. 26). Remembering the campus-based participatory movements and the service-learning leaders of our past reminds us that our movement today can be so much more than it has yet become.

\section{Echoes of the Activist Past: CU-Denver's Westside Outreach Center}

Today, a CU-Denver service-learning center (the Westside Outreach Center) offers an advocacy-oriented, insurgent brand of service-learning that is modeled on such historical examples as Hull House and SDS. The Westside Outreach Center (WOC) tends to place service-learning students into partnerships with obstreperous tenant activists, with homeless activists notorious for their resistance to shelter paternalism, with TANF (Temporary Assistance for Needy Families)-dependent families at odds with their local welfare office, and with neighborhood activists who have little faith in established nonprofits or city agencies. In detailing these programs and their educative benefits, I will also examine how faculty and students involved in WOC have found themselves under pressure by both their nonprofit partners and by government officials to moderate their politics and work as agents of normalization and professionalization when confronted by episodes of insurgent street politics.

WOC is a program of CU-Denver dedicated to channeling university resources into efforts to organize and revitalize a campus-bordering Latino barrio known as "The Westside." The center is funded by a large HUD Community Outreach Partnership Center grant, with substantial matching funds from the university and from a community development corporation partner (NEWSED). WOC seeks to achieve neighborhood revitalization goals by bringing funded student interns, subsidized faculty, and entire "service-learning" courses (e.g., "Community Organizing and Development" and "Politics of Nonprofits") into action-engagement with lowincome neighborhoods bordering the campus of CU-Denver. The Center hires about fifteen servicelearning students each semester to engage in community work in the neighborhood; many of these students stay involved semester after semester. Associated service-learning classes by various faculty members bring more students. All told there are usually about forty student employees or interns of WOC working each semester in community organizing in the Westside.

From the start, WOC had to decide how aggressive the center could be in using its resources to advance politically charged activities. In channeling 
students into neighborhood organizing and other service-learning efforts, should I (as WOC's director) urge students to foster conflict with landlords and elected officials, to help residents organize street demonstrations, and to discuss such possibilities as squats and rent-strikes? Or should I (as I was persistently advised by many faculty colleagues, including those in the service-learning movement) steer clear of such conflict-ridden organizing methods and instead focus on consensual social-capital building exercises such as block parties, neighborhood watches, property rehab efforts, art shows, and conflict-resolution classes?

In considering such options, WOC had to make a fundamental choice. Should this service-learning program ally with state agencies and with the professionalized nonprofit community, assisting these groups with their case management practices, their direct services (tutoring, family counseling,), and their physical revitalization activities (building new homes and rehabilitating rundown properties), or should WOC funnel the idealistic energies of youth into insurgent community organizing, protest politics, and the grassroots mobilization of people distrustful of both the state and many nonprofits?

WOC's choice was to take the more unpredictable and potentially radical stance, allying with an increasingly turbulent movement of tenant activists and with small neighborhood-based groups, and keeping our distance from city agencies and from some of the largest and most professional nonprofit organizations. It involved placing students into service-learning partnerships with a defiant tenants movement (the Save Our Section 8 housing Coalition), with a group of radical neighborhood planning activists (as opposed to working with the City Planning Department), and with a welfare rights coalition (organizing against the policies of Denver social service agencies). All of these experiences involved students in explicitly political advocacy work and all involved struggling against the advice and admonitions of city officials and some established nonprofit groups to play a more accommodating and professional role. I will speak briefly of each of these politicized service-learning campaigns, attempting in each case to elucidate how it is that serious political and educational choices are involved in choosing to work for or against city agencies, for or against established non-profits, for or against standards of professional neutrality.

\section{The Save Our Section 8 Coalition}

The defining event of the Save Our Section 8 (SOS8) tenant organizing campaign revolved around low-income tenants' disruptive response to Denver's official affordable housing efforts and the position in which that response put WOC students and faculty. In brief, the situation was as follows. Throughout 1998 and 1999, WOC service-learning students had worked with grassroots tenant leaders and other Denver community organizing groups to build a coalition of tenants dedicated to forcing the lowincome housing crisis to the front of the city's agenda. When this housing coalition (SOS8) was met with the official response that more research on the crisis was needed and that the issue would be further discussed following a long process of research and professional planning, WOC interns worked with hundreds of tenant activists who took to the streets and consistently packed city council chambers in protest, demanding to be heard, even though they were not on the agenda.

The tactics worked, and the city responded by forming an affordable housing task force, including members of the SOS8 coalition, and relying on the SOS8 coalition for much of its initial direction and supporting research data (gathered largely by WOC service-learning students). Within a few months, however, the affordable housing task force began to slow its work, refusing to bring new housing ordinances before council, and targeting most new affordable housing assistance money to those earning $\$ 30,000-\$ 45,000$ a year. Again, SOS8 worked with WOC service-learning students to expose these failures, and to mobilize hundreds of low-income residents to attend task force meetings, disrupt the proceedings, and literally to take over the podium to express their discontent.

It is revealing that city officials, together with local HUD staff and even a representative of a local non-profit, joined to call a meeting with WOC staff to voice their concern with involving service-learning students with this kind of disruptive and defiant street politics. We were informed that students should not be adversaries of HUD and the city, but should be allies and "research associates." Our role was to provide necessary technical research, and to better educate community insurgents as to the realistic limitations of housing policy and to the wisdom of working cooperatively with city officials, not against them. The nonprofit representative informed us that their organization stood to receive more money from the city for their homebuyer education workshops, and that WOC would do better to work on the homebuyer education project and on grantwriting assistance, rather than on riling up neighborhood activists for an unwinnable low-income housing campaign. In other words, we were asked to play the role of moderating the insurgents' anger, numbing the force of protest with the cool logic of university-educated reason, and working to advance the agenda of the official task force and the community 
development corporations funded by the city, not the agenda of the neighborhood protesters.

Service-learning programs face vital political and educational choices when they decide with whom to ally. A very different kind of affordable housing politics, and a very different student education, emerge from joining with the moderate forces of the affordable housing task force and its associated non-profit homeownership counseling programs than from linking students to the low-income renters' insurgency of the SOS8 coalition. Why is there so little involvement of service-learning programs in insurgent SOS8-type movements nationwide, and what is the political and educational effect of linking students to official task force efforts and professional community development corporation programs, while street-level low-income housing movements go begging for support?

\section{Neighborhood Planning: \\ Boardrooms or Barricades?}

A second vignette involves the official efforts of the city planning department to update the neighborhood plan of the low-income Westside community that was suffering intense gentrification pressures. In their beginning planning efforts, the planning department made it clear to residents that many of these gentrification trends were considered positive by city officials in that they brought upper income residents into the inner-city, increased the city's tax base, and mitigated the social problems of lowincome communities. This philosophy, favoring inner-city gentrification, was presented clearly in a position paper by Denver's Planning Director, Jennifer Moulton (1999).

When neighborhood residents and WOC servicelearning students met with city planners to express concerns that such a vision would deplete lowincome housing stock, contribute to a housing crisis for the poor, and fundamentally transform their community, a planner made the telling remark that "neighborhood activists will not dominate this plan. You must understand that this community has to find a way to fit into the overall plan for the entire city. Should we protect the low-income community that currently exists? Well, we feel that this area is not really a viable community in the first place. Maybe we should think of this neighborhood as an extension of downtown; as a place for Denver's new workers [e.g., affluent loft-dwellers] to live."

In subsequent meetings with WOC, city planners made it clear that the proper role of a service-learning student involved in neighborhood planning was to serve as a politically neutral expert, refusing to take sides in conflicts, but only offering advice and data on such subjects as traffic flow, land use pat- terns, and crime rates. Urban planning students were told that their role was to help the neighborhood work cooperatively with downtown designers and with the planning department, not to stir up political discontent, nor to independently mobilize hundreds of residents to engage the planning process. Rather, the city would set up a series of neighborhood meetings (on its own schedule), would appoint a neighborhood plan steering committee, and would work with a limited cadre of local representatives to assess the neighborhood sentiment.

Regardless of this advice, WOC has channeled its urban planning service-learning students into neighborhood-based efforts to resist the world view offered by city planners and to organize and express an alternative vision of the neighborhood. WOC service-learning students have produced research documenting the dangers of gentrification, have detailed the mismatch between high-rise zoning codes and existing low-rise uses, and have educated residents as to the more progressive planning options that are available to city planners. WOC students have organized dozens of neighborhood planning meetings, independent of the planning department, with the aim of building a strong group of neighborhood residents who can independently engage the planning department and city council to demand that their own vision be taken seriously. WOC students are working with residents to force the city planning department to bring the market forces of destabilization and redevelopment to a halt in their community.

As the city continues to stall on moving the neighborhood plan forward, WOC is working with a neighborhood preservation committee to independently design a community-drafted neighborhood plan. This plan will then be presented to city council, backed up by a defiant group of neighborhood residents, with or without the participation of the planning department. Already, WOC students have helped mobilize about 300 low-income neighborhood residents to the city's public celebration of its "Comprehensive Plan 2000," a plan celebrating Denver's recent growth and the gentrification of inner-city communities. Completely unexpected, hundreds of residents turned out to an event meant to praise Denver's gentrifying planning director, and took over the process with several angry hours of testimony.

Important educational choices are involved in channeling future student planners and administrators into service-learning opportunities with official city agencies and established city planning processes. Usually these agencies and processes have a bias toward a given agenda, and they always prefer political stability and predictability over the disruptive 
spontaneity that is inevitable when hundreds of residents are mobilized to participate in city government. Service-learning advocates should carefully scrutinize the political and educational implications of building service-learning programs around cooperation with city agencies and around assumptions that an administrator's role is to be a dispassionate and neutral expert. Other models of advocacy planning and neighborhood mobilization exist, but service-learning programs are rarely built around them.

\section{The TANF Research and Organizing Campaign}

Throughout Denver, as in America, there has been very little organized response by TANF recipients to the challenges entailed by the Personal Responsibility and Work Opportunity Act (PRWOA: i.e., welfare reform or TANF). Nearly twenty years of hostility to recipients of public aid has created a public impression that service-dependency is a sign of personal failing and that an appropriate state response is a combination of diminished aid and behavioral control/modification. The new rules of the PRWOA reflect these values in that they impose time-limits to public aid and allow states to impose significant behavioral controls (recipients must enroll in personal work plans, must attend counseling meetings, must not be caught with controlled substances, etc.). Any alternative viewpoint (e.g., that TANF recipients deserve higher levels of aid, more autonomy, and less demeaning pressure from relief agencies) is rare in today's discourse.

In WOC's neighborhood, these realities play out in the Denver Housing Authority's (DHA) newest Public Housing community: North Lincoln Housing. Though this housing development offers quality public housing, it is managed to parallel the TANF requirements in that its residents are timelimited (five years) and they must agree to strict behavioral controls. Residents must attend regular group therapy sessions, they must receive individualized counseling for personal and work issues, they must be working or engaged in a job search, they must not miss or be late to appointments with their case managers, and they must not use alcohol in public or controlled substances of any kind. Violating these rules leads to a "three strikes and you're out" policy.

Local nonprofits have been enlisted in the new welfare philosophy, receiving substantial funding streams from the city and from foundations to design case-management programs and sophisticated management information systems to track individual client progress. Nonprofits are being funded to design welfare-to-work counseling programs, drug and alcohol counseling programs, family crisis counseling, and even to supervise and punish recip- ients of aid who do not live up to the new rules and regulations. Very little nonprofit money or programming now goes into organizing and advocacy efforts with the TANF-dependent community, or into efforts to challenge and expand the steadily diminishing welfare state. Like the broader political community, many local nonprofits have substituted a personal case-management approach for a broader political advocacy approach to poverty.

From the start, WOC students were offered service-learning opportunities helping DHA to run its case management/client-counseling services and its tutoring and after-school programs. A local nonprofit offered placements in its family counseling/ domestic violence counseling programs, maintaining its client-tracking management information system, and helping with youth skills development programs.

But other social welfare service-learning opportunities, less well-funded and less mainstream, existed in the community-namely working with groups of concerned TANF recipients that were organizing to resist welfare-reform, to challenge the supervisory and patronizing programs of DHA, and to transform the case-management approach that dominates nonprofit work. These residents were building a political campaign to restructure welfare administration and to challenge the emerging complicity between the state and many local nonprofits, who together are building a supervisory approach to poverty.

WOC has chosen to channel most of its students who are studying the politics of nonprofits into partnerships with these political campaigns (e.g., People United For Families, Humanity for the Homeless) while urging students to carefully consider the political implications of working with state and nonprofit programs of client supervision and case-management. WOC funds students to act as organizers and research assistants in the TANF community, and they have worked to establish a welfare-rights group for the purpose of political advocacy and to bring TANF recipients together to act as peer advocates in dealing with the Department of Social Services. Service-learning students also serve as personal advocates for families dealing with DSS officialseducating TANF recipients as to their rights, helping them to confront administrators, and inviting them to join in a political campaign to urge the Denver Welfare Reform Board to dedicate more money to housing assistance for TANF-clients.

A review of programs nationwide indicates that most service-learning students involved with TANFdependent populations are being channeled into client-counseling, tutoring, after-school programs, case-management, or technical non-profit administration work, such as fund-raising and management 
information systems. In so doing, students become complicitous with modern welfare reform trends, and learn to personalize rather than politicize poverty. Such programs have their virtues and there is a place for them, but service-learning programs need to balance these placements by also exposing students to the full range of political stances that a student or a community may take in response to welfare reform.

\section{Dare Progressive Education be Progressive?}

George Counts (1932) directed this question to his peers in the education community. Though he was pleased to see the attention paid to a renewed theory of socially relevant progressive education, he questioned the easy optimism of his peers regarding the potential of progressive education to rebuild social connections and leverage social progress. He did not believe leaders in the movement were truly ready to struggle alongside the poor and to adopt the political causes of the underclass as their own. He was pessimistic about the willingness of the universities to "struggle and sacrifice" in the name of the poor, to "wage war on behalf of principle or ideal," or to commit seriously to the cause of social transformation. Instead, his peers often followed mild programs of individualistic liberal charity that were based on "good will and humane sentiment," but that were "entirely incapable of dealing with any of the great crises of our time" (pp. 3-8).

Counts' concerns remain relevant today. Dare the service-learning movement commit to transformation? Dare the schools build a new social order? Dare we seriously adopt Rhoads' (1997) concept of a "critical education" that "prepares students to be their own agents for social change, their own creators of democratic culture" (p. 204)? I am not arguing that all service-learning programs should be structured so as to promote radicalizing educative experiences, or to advance a politically transformational pedagogy. Rather, I am only arguing that more programs should be so structured and that academics should be more constructively critical of the overwhelmingly institutionalized and mainstream nature of typical service-learning programs. If the servicelearning movement cannot push its boundaries dramatically, then we may expect only marginal effects in leveraging social progress, and we may expect educational results that narrowly domesticate our students' natural inclination to right wrong and to achieve social justice. I am aware of the danger that both HUD and the university community may come to second-guess the involvement of students and faculty in contentious advocacy-politics. But the moment is now for the Westside Outreach Center, and while it lasts, we will stand in the tradition of
Jane Addams and SDS, pushing as far and as hard as we can to achieve social transformation.

Scholars such as Zlotkowski and Mayhew (1968) are right - the university community as a whole is unlikely to accept such a transformational mission, and "there is always the counterrevolution standing in the wings with its appeal to ordered convention" (Mayhew, p. 147). This is true. And when the moment of social progress passes, as it always will, it will be left to the accommodationists to consolidate the gains-but it must be remembered that whatever serious gains there are to consolidate will not have been won in acts of charitable giving to the needy, but in moments of political struggle against the prevailing order.

But what of the potential for such a program to violate the "principle of academic neutrality"? Professors must not let their agendas overwhelm their teaching or their students, we are constantly reminded. There are two responses to this charge. First, an appropriate "justice-advocacy" servicelearning program will, of course, offer alternatives to those students not wishing to participate in such activities and campaigns. Occasionally, some students take exception to the left-leaning, transformational agenda of WOC. As a professor's obligation is to teach analytical and political skills to all students without requiring orthodoxy of either action or thought, I strive to productively integrate such student resistance into the course. Achieving such a result is not too difficult.

First, this program is an elective and few students participate in WOC without self-selecting. Students generally come to WOC knowing what to expect and are excited by the project. Still, students come from all variety of value-orientations. To welcome all perspectives, it is made clear that, although certain action projects are laid out by the professors, any student or group of students can design a project of their choice, as long as it involves engagement with residents of a low-income urban neighborhood. Alternative student projects have included marketing community arts and culture businesses, creating local business plans, working to bring more police attention to the community, and creating a hockey league for children from the area's public housing projects. Students sponsoring these projects were all more conservative than the average WOC student, and it was a great benefit to incorporate their broader perspectives into student discussions about urban poverty and the proper response to it.

In one example, a WOC service-learning class had attracted a student who was actually a landlord of a HUD-subsidized Section 8 housing project, and he was opting out of the program - the very kind of landlord targeted for action by WOC's 
affordable housing tenant campaign. My response was to work with this student, who was originally very disgruntled at the value orientation of the class, to establish a series of discussion forums in class that included Section 8 landlords (organized by the landlord student) and low-income tenants (organized by other WOC service-learning students). The forums brought two initially opposed groups together for frequent conversation, played a wonderful educative role in the class, and provided the landlord-student with a satisfying strategy to work with WOC in a way that did not compromise his own political views. Using this kind of strategy to open the classroom to discussions of the underlying political assumptions of the action choices of students has led to broad satisfaction among a wide range of students.

The second response to the "neutrality" argument is that such a "biased" program cannot possibly violate a principle of neutrality that does not, in fact, exist. Universities are filled with classes training students to accept and thrive within the conventional boundaries of established professions. They are filled with classes defending the rights of the business community. They are filled with classes tracking student interns into service with police departments, prisons, governor's offices, and law offices; how can pairing interns with other types of political campaigns be unduly "biased" simply because these offices are not among mainstream powers of society? In fact, programs such as WOC help preserve University "neutrality" by creating a broader range of options for students seeking to discover and round out their political identify. Already there are plenty of courses offering students opportunities to flourish within the accepted boundaries of American politics and economics: just look to the Schools of Business and Departments of Economics. A single elective program such as the Westside Outreach Center, in the midst of a vast and diverse university, has little power to oppressively indoctrinate students.

Nevertheless, it is almost certainly the case, as Zlotkowski (1996) has observed, that the kind of service-learning project described here is unlikely to attract widespread or lasting university support. It is too politically charged, it privileges broad political and social goals over educating students in the "basics," and it involves the university community in risky social conflict. But surely one of the grand roles of the educated, since the days of Socrates, has been to speak truth to power, to wage war for principle, to build the intellectual, moral and civic power of those communities that have little else to stand on. Though we can expect that the servicelearning movement may not last, especially in its justice-advocacy genre, we must neglect calls to moderate and thereby accommodate the movement to a broader range of funders and university supporters. Rather, our charge is to grasp what power we can, claim the mantle of the university as the spark and engine of social progress, powerfully advance our political and moral principles, and use this opportunity to educate students on both the possibilities and the strategies of participatory politics. Meek acceptance of authoritative guidelines to remain "neutral" and "non-political" will shrink the parameters of the possible and decrease the relevance of any service-learning movement to the low income communities it ostensibly serves. The service-learning movement, if pushed to the transformational limits suggested in its own rhetoric, may be expected to leverage great changes, while simultaneously arousing deep resistance. It will catalyze fundamental social progress, even as it dissipates its broader social support. Thus passes any great-but ultimately temporal—reforming wind.

\section{References}

Addams, J. (1910). Twenty years at Hull House. New York: Signet.

Arnove, R. (Ed.). (1982). Philanthropy and cultural imperialism: The foundations at home and abroad. Bloomington, IN: Indiana University Press.

Bailey, R. \& Brake, M. (1975). Introduction: Social work and the welfare state, In R. Bailey \& M. Brake (Eds.), Radical social work (pp. 1-13). New York: Pantheon.

Barber, B. (1999, May). Address to the National Conference of the Campus Compact. Phoenix, AZ.

Barber, B. (1998). A mandate for liberty: Requiring education-based community service. In A. Etzioni (Ed.), The essential communitarian reader (pp. 237-245). New York: Rowman and Littlefield.

Barber, B., \& Battistoni, R. (1993). A season of service: Introducing service learning into the Liberal Arts curriculum. PS: Political Science \& Politics, 26, 235-241.

Bass, M. (1997). Citizenship and young people's role in public life. National Civic Review, 86, 203-211.

Boyte, H. \& Farr, J. (1997). The work of citizenship and the problem of service-learning. In R. Battistoni and W. Hudson (Eds.), Experiencing citizenship: Concepts and models for service-learning in political science (pp. 3548). Washington, DC: American Association for Higher Education.

Carpini, M. \& S. Keeter. (2000). What should be learned through service learning. PS: Political science and politics, 33, 635-637.

Carr, J. (1999). It's not just academic: University-community partnerships are rebuilding neighborhoods. Housing Facts and Findings, 1, 1-5.

Chickering, A. (1998). Why we should encourage student activism. About Campus. January-February, 2-3.

Clotfelter, C. (Ed.). (1992). Who benefits from the nonprofit sector? Chicago, IL: University of Chicago Press. 
Cloward, R. \& Piven, F. (1975). Notes towards a radical social work. In R. Bailey \& M. Brake (Eds.), Radical social work (pp. vii-xvii). New York: Pantheon.

Commager, H. (1960). Foreword. In J. Addams, Twenty years at Hull House (vii-xvi). New York: Signet.

Commoner, B. (1968). The dual crisis in science and society. In G. K. Smith (Ed.), Stress and campus response (pp. 15-26). San Francisco: Jossey-Bass.

Counts, G. (1932). Dare the school build a new social order? New York: John Day.

Etzioni, A. (1983). A remedy for overeducation - A year of required national service. Change, 15: May/June, 8-12.

Finn, C. E. Jr., \& Vanourek, G. (1995). Charity begins at school. Commentary, 100, 4, 46-49.

Gitlin, T. (1989). The Sixties: Years of hope, days of rage. New York: Bantam Books.

Gorham, E. (1992). National service, citizenship, and political education. New York: State University of New York Press.

Gugerty, C. \& Swezey, E. (1996). Developing campuscommunity relationships. In B. Jacoby (Ed.), ServiceLearning in higher education: Concepts and practices (pp. 92-108). San Francisco: Jossey-Bass.

Hepburn, M., Niemi, R. \& Chapman, C. (2000). Service learning in college political science: Queries and commentary. PS: Political science and politics, 33, 617-621.

Harkavy, K. \& Benson L. (1997). De-Platonization and the democratization of education as the bases of service-learning. On-line version located at http://www.upenn.edu/Bibliography/Service_Learning. html

Harrington, M. (1968). The university and the problem of poverty. In G. K. Smith (Ed.), Stress and campus response (pp. 43-51). San Francisco: Jossey-Bass.

Horwitz, C. (1993). What is wrong with national service? Social Policy. Online version located at http://www.socialpolicy.org/back_issues/FL93/horwitz.html.

HUD. (1999). Building higher education-community development corporation partnerships. Washington, DC: US Department of Housing and Urban Development.

James-Deramo, M. (1999). Hunger for justice: Servicelearning in feminist/liberation theology." In K. Weigert \& J. Crews (Eds.), Teaching for Justice: Concepts and Models for Service-Learning in Peace Studies (pp. 137150). Washington, DC: American Association for Higher Education.

Kahne, J., \& Westheimer, J. (1996). In the service of what? The politics of service-learning. Phi Delta Kappan, 77, 592-600.

Katz, M. (1996). In the shadow of the poorhouse: A social history of Welfare in America (revised and updated). New York: BasicBooks.

Kraft, R. (1998). Service learning: An introduction to its theory, practice, and effects. In J. Craig (Ed.), Advances in education research (pp. 7-23). Washington DC: National Library of Education.

Lisman, C. D. (1998). Toward a civil society: Civic literacy and service learning, Westport, CT: Bergin and Garvey.
Mayhew, L. (1968). A rendering of accounts. In G. K. Smith (Ed.), Stress and campus response (pp. 144-156). San Francisco: Jossey-Bass.

Mayo, M. (1975). Community development: A radical alternative? In R. Bailey \& M. Brake (Eds.), Radical social work. (pp. 129-143). New York; Pantheon.

Mead, L. (Ed.). (1997). The new paternalism: Supervisory approaches to poverty. Washington, DC: Brookings Institute Press.

Mendel-Reyes, M. (1995). Reclaiming democracy: The Sixties in politics and memory. New York: Routledge.

Mendel-Reyes, M. (1997). Teaching/theorizing/practicing democracy: An activist's perspective on service-learning in political science. In R. Battistoni \& W. Hudson (Eds.), Experiencing citizenship: Concepts and models for service-learning in political science (pp. 15-34). Washington DC: American Association for Higher Education.

Miller, J. 1987. Democracy is in the Streets: From Port Huron to the siege of Chicago. New York: Simon and Schuster.

Moulton, J. 1999. 10 steps to a living downtown. A discussion paper prepared for the Brookings Institute: Center for Urban and Metropolitan Policy. Washington, DC: The Brookings Institute.

Nyden, P., Figert, A., Shibley, M. \& Burrows, D. (1997). Building community: Social science in action. Thousand Oaks, CA: Pine Forge Press.

Pickeral, T. (1996). Of the faculty, by the faculty, for the faculty. In T. Pickeral \& K. Peters (Eds.), From the margin to the mainstream: The faculty role in advancing service-learning on community colleges (pp. 3-9). Mesa, AZ: Campus Compact National Center for Community Colleges.

Piven, F. F., \& Cloward, R. (1977). Poor people's movements: Why they succeed, how they fail. New York: Pantheon.

Piven, F.F. \& Cloward, R. (1993). Regulating the poor: The functions of public welfare (updated edition). New York: Vintage.

Putnam, R. (1995). Bowling alone: America's declining social capital. Journal of Democracy, 6, 65-78.

Rhoads, R. (1997). Community service and higher learning. New York: State University of New York Press.

Rimmerman, C. (1997). The new citizenship: Unconventional politics, activism, and service. Boulder, CO: Westview Press.

Rocha, C. J. (2000). Evaluating experiential teaching methods in a policy practice course: The case for service-learning to increase political participation. Journal of Social Work Education, 36, 53-60.

Salamon, L. (1992). Social Services. In R. Clotfelter (Ed.), Who benefits from the non-profit sector? (pp. 134-173). Chicago: University of Chicago Press.

Schaps, E., \& Lewis, C. C. (1998). Breeding citizenship through community in school. The Education Digest, 64, 23-27. 
Stringer, E. (1997). Community-based ethnography: Breaking traditional boundaries of research, teaching and learning. Mahwah, NJ: Lawrence Erlbaum Associates.

Walker, T. (2000). The service/politics split: Rethinking service to teach political engagement. PS: Political science and politics, 33, 647-649.

Wolch, J. (1990). The shadow state: Government and voluntary sector in transition. New York: The Foundation Center.

Zlotkowski, E. (1996). Linking service-learning and the academy. Change, 28: (Jan/Feb), 20-27.

\section{Author}

TONY ROBINSON is an assistant Professor at the University of Colorado at Denver, where he specializes in urban grass-roots politics, coordinates his department's internship program-the "CU in the Capitol" legislative internship program-and his department's service-learning graduation requirement. He also serves as the Director of UC-Denver's Westside Outreach Center for community organizing and development. His publications mainly concern service-learning pedagogy and practice, grassroots movements, and urban political economy. 